\title{
Prevalence and distribution of thalassemia trait screening
}

\author{
Nailil Husna, Immanuel Sanka, Ahmad Al Arif, Chintya Putri, Elory Leonard, Niken Satuti \\ Nur Handayani* \\ Laboratory of Genetics and Breeding, Faculty of Biology, Universitas Gadjah Mada, \\ Yogyakarta, Indonesia
}

DOI: http://dx.doi.org/10.19106/JMedSci004903201702

\begin{abstract}
Thalassemia is an inherited disorder of autosomal recessive gene caused by decrease or absent production of one or two type of globin chain. This disorder will affect the quality and quantity of blood production. In Indonesia, thalassemia is not concerned as urgency, although it lies in thalassemia belt area. Thalassemia is classified according to the particular globin chain which affected such as $\alpha$-thalassemia and $\beta$-thalassemia. Besides thalassemia, there are variant hemoglobinopathy called HbE. The aim of this study was to assess the prevalence of thalassemia carriers among the volunteer of screening in Yogyakarta Special Region from 2012 until 2015. The thalassemia carrier screening was conducted by collaborating with Indonesian Association of Parents of Children with Thalassemia (APCT) Yogyakarta. The hematological measurement and High-Performance Liquid Chromatography (HPLC) were performed on Prodia Laboratory Yogyakarta. The analysis of carriers prevalence was conducted in Laboratory of Genetics and Breeding, Faculty of Biology, Universitas Gadjah Mada, Yogyakarta. Among 241 volunteers, we found 44 volunteers was diagnosed as $\beta$-thalassemia carrier, 30 volunteers as $\alpha$-thalassemia carrier as well as $\mathrm{HbE}$ disorder carrier, and 1 volunteer was diagnosed as $\alpha-\beta$-thalassemia carrier. The number of thalassemia carrier shows no significant difference each year. The prevalence of thalassemia carrier is high, even though the distribution is limited by the location where the screening took place.
\end{abstract}

\section{ABSTRAK}

Thalassemia adalah kelainan bawaan pada gen resesif autosomal akibat penurunan atau tidak diproduksinya satu atau dua jenis rantai globin. Kelainan ini mempengaruhi kualitas dan kuantitas produksi darah. Di Indonesia, thalasemia belum menjadi masalah penting walaupun lokasinya termasuk dalam daerah sabuk thalasemia. Thalasemia diklasifikasikan berdasarkan rantai globin yang mengalami mutasi yaitu $\alpha$-thalasemia dan $\beta$-thalasemia. Selain thalasemia, ada satu varian hemoglobinopati yang disebut $\mathrm{HbE}$. Tujuan dari penelitian ini adalah untuk menentukan prevalensi thalasemia di antara relawan skrining di Daerah Istimewa Yogyakarta dari tahun 2012 sampai 2015. Skening thalasemia dilakukan dengan bekerjasama Perhimpunan Orang tua Penderita Thalasemia Indonesia (POPTI), Daerah Istimewa Yogyakarta. Pemeriksaan hematologi dan High-Performance Liquid Chromatography (HPLC) dilakukan di Laboratorum Klinik Prodia, Yogyakarta. Analisis prevalensi pembawa gen thalasemia dilakukan di Laboratorium Genetik dan Pemuliaan, Fakultas Biologi, Universitas Gadjah Mada, Yogyakarta. Dari 241 sukarelawan yang diskrining, 44 sukarelawan didiagnosis sebagai pembawa $\alpha$-thalasemia, 30 pembawa

$\overline{\text { Corresponding author: fniken_satuti@ugm.ac.id }}$ 
$\beta$-thalasemia dan $\mathrm{HbE}$ serta satu pembawa $\alpha-\beta$-thalasemia. Jumlah pembawa thalasemia tidak menunjukkan perbedaan yang signifikan setiap tahunnya. Prevalensi pembawa thalasemia tinggi, meskipun distribusinya dibatasi oleh lokasi dimana skrining dilakukan.

Keywords: Thalassemia trait screening - $\alpha$-thalassemia - $\beta$-thalassemia - HbE - HPLC

\section{INTRODUCTION}

Thalassemia is an inherited disorder of autosomal recessive gene caused by decrease or absent production of one and/ or two type of globin chain. This disorder will affect the quality and quantity of blood production. ${ }^{1} \quad$ Thalassemia is classified according to the particular globin chain which affected. The $\alpha$-globin is involved in $\alpha$-thalassemia and the $\beta$-globin chain is affected in $\beta$-thalassemia. ${ }^{2,3}$ Approximately 400 mutations have been reported to cause this disorder in the world population. ${ }^{4,5}$ The mutation can cause hereditary anemias due to decrease hemoglobin synthesis and red blood survival. ${ }^{6}$ Beside, structural hemolgobin variant known as hemoglobinophaty are also caused by abnormality in globin chain such as $\mathrm{HbS}, \mathrm{HbC}$ and $\mathrm{HbS}^{7}$

Previous studies reported that the distribution of this disorder were limited to the areas called "thalassemia belt" (lies from the Mediterranean basin through the Middle East and Indian subcontinent up to Southeast Asia), but recent migration of people have spread thalassemia genes throughout the world. ${ }^{6,8}$ About $7 \%$ of the population was recorded inherit the disorder throughout Africa and Asia. ${ }^{1}$ In Indonesia, thalassemia is not considered as major health problems, although it lies in thalassemia belt area. Furthermore, thalassemia carrier in Indonesian population was recorded and shown high prevalence, for detail $3-20 \%$ was $\alpha$-thalassemia carrier, $3 \%$ was $\beta$-thalassemia carrier and $1-33 \%$ was HbE carrier. ${ }^{9}$
The thalassemia trait which inherits an individual only has mutation from one of the parents. ${ }^{1}$ The thalassemia trait does not suffer thalassemia, but if the trait marry another trait, there would be a chance to have thalassemia major disorder or severe anemia. ${ }^{10}$ Refer to the population which reported above, this study was conducted to to assess the prevalence of thalassemia carriers among the volunteer of screening in Yogyakarta Special Region from 2012 until 2015.

\section{MATERIALS AND METHODS}

\section{Volunteers}

The material of this research was the hematological database as the result of screening from Prodia Clinical Laboratory, including 241 sheets of cellular medical test which contain quantity of cellular blood components. Thalassemia screening was conducted annually and collaborated with Indonesian Association of Parents of Children with Thalassemia (IAPCT) Yogyakarta, the Indonesia Thalassemia Foundation (ITF), Prodia Clinical Laboratory, Yogyakarta and Faculty of Biology Universitas Gadjah Mada, Yogyakarta. From 2012 until 2015, there was 241 volunteers who attended the screening.

\section{Procedure}

Blood collection was conducted in Faculty of Biology, Universitas Gadjah Mada, Yogyakarta. The hematological measurement and High-Performance Liquid Chromatography (HPLC) were performed in 
Prodia Clinical Laboratory, Yogyakarta. To define the thalassemia prevalence, the analysis was conducted in Laboratory of Genetics and Breeding, Faculty of Biology, Universitas Gadjah Mada, Yogyakarta. Informed of consent was obtained from the volunteer who observed.

\section{Analysis}

The data was analyzed using formula of Microsoft Excel 2010 due to the assigned ranged from Prodia Clinical Laboratory, Yogyakarta. The analysis was conducted in Laboratory of Genetics and Breeding, Faculty of Biology, Universitas Gadjah Mada, Yogyakarta.

\section{RESULTS}

There were 241 volunteers which measured on the thalassemia screening. From the screening we found 75 volunteers who have thalassemia trait, meaning that almost $45 \%$ of the volunteer were diagnosed disorder. FIGURE 1 shows the prevalence of thalassemia among volunteers screened. The $\beta$-thalassemia trait was recorded most often which reached out 44 volunteer, while it was founded that $\alpha$-thalassemia carrier and $\mathrm{HbE}$ disorder carrier had the same number of 30 volunteers. However, we found one volunteer who had $\alpha$ - $\beta$-thalassemia carrier phenotype. FIGURE 2 shows that the prevalence for female of thalassemia carrier and $\mathrm{HbE}$ disorder carrier were higher than male.

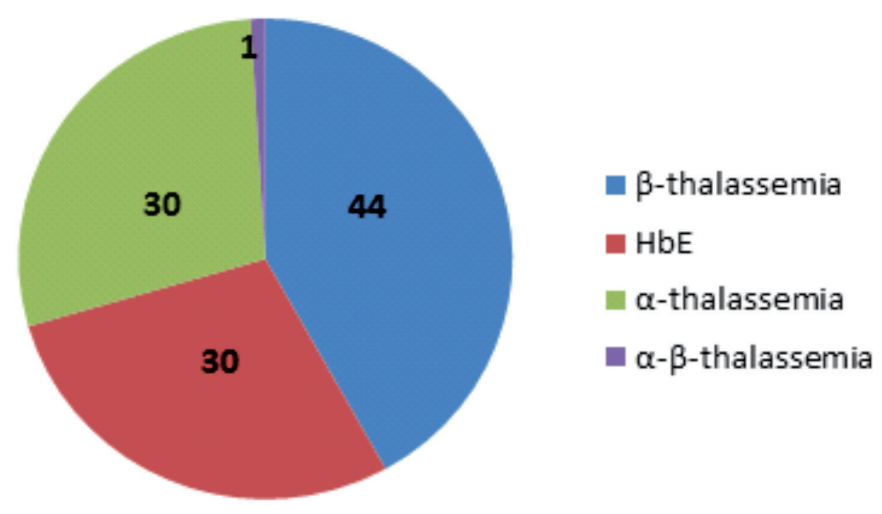

FIGURE 1. The prevalence of thalassemia among volunteers screened.

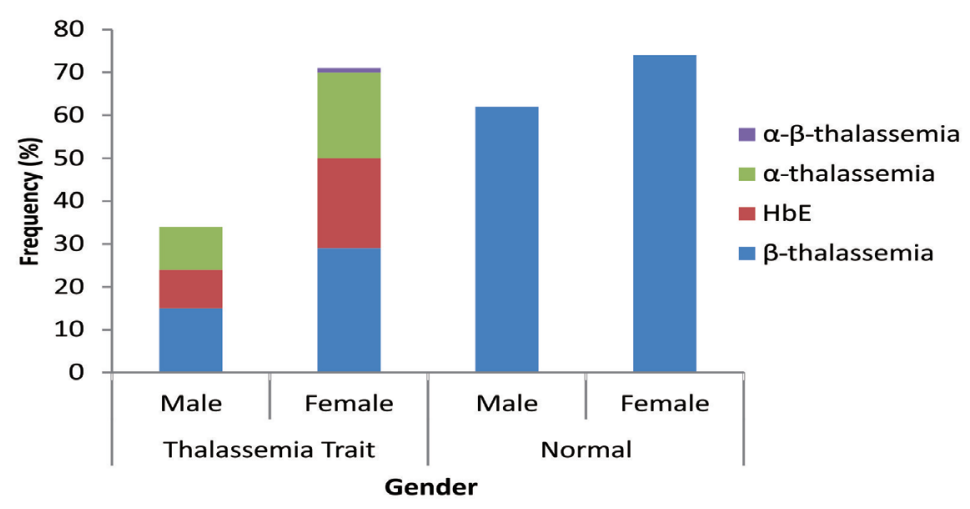

FIGURE 2. The prevalence of thalassemia among volunteers screened based on gender 
FIGURE 3 shows the prevalence of thalassemia trait in four different years from 2012 to 2015 . The total number of thalassemia carrier showed no significant difference from 2012 to 2015. For $\alpha$-thalassemia carrier, in 2012 the number for volunteer with the carrier was lower than $\beta$-thalassemia carrier (9 volunteers detected). But, different with 2013, the number of volunteers detected with $\alpha$-thalassemia carrier was the highest among other thalassemia carrier (13 volunteers detected). In 2014 and 2015, the number of $\alpha$-thalassemia carrier was the lowest among others, which were 6 and 2 volunteers detected respectively. The number of carrier prevalence for $\beta$-thalassemia carrier in 2012 and 2015 was the highest comparing to other thalassemia carriers. In 2013, its prevalence was the lowest among others, and in 2014, number of prevalence for $\beta$-thalassemia carrier was ranked number two. Also in 2012, we obtained a volunteer with $\alpha$ - $\beta$-thalassemia carrier phenotype. $\mathrm{HbE}$ disorder carrier was firstly found in 2013 screening with stable number in the next year of screening and it fluctuated between 9-11 volunteers detected with the carrier.

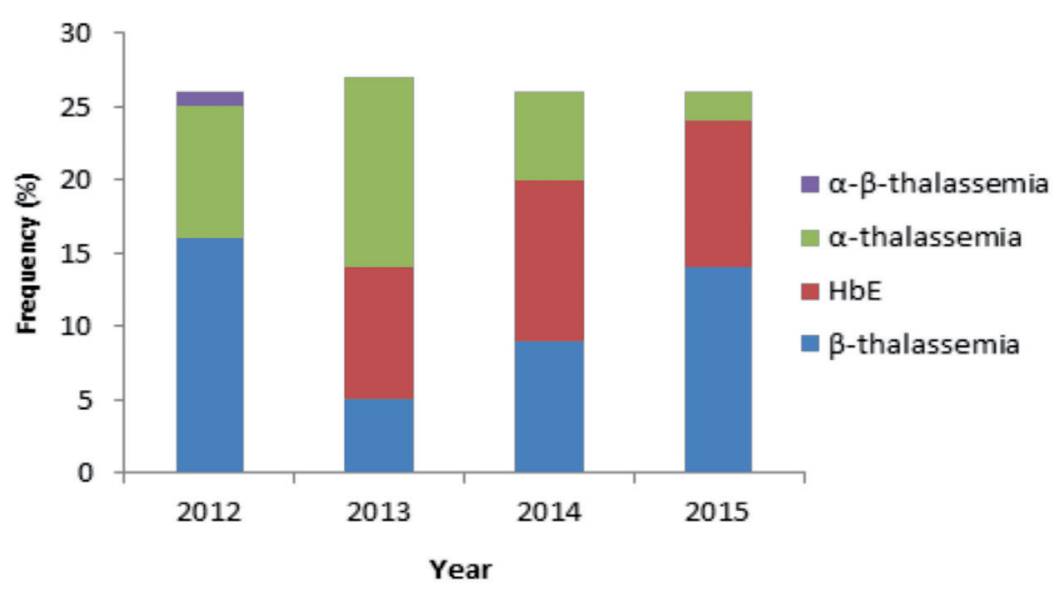

FIGURE 3. The prevalence of thalassemia trait in four different years.

FIGURE 3 shows the distribution of thalassemia carrieraccording to their respective native region detected in five provinces, which are Yogyakarta Special Region, Central Java, East Java, South Sumatra and Riau. Based from the screening, the most often thalassemia carrier was recorded on province Yogyakarta Special Region, followed by Central Java, and East Java. In Yogyakarta Special Region and Central Java, all of the thalassemia carriers were detected. 


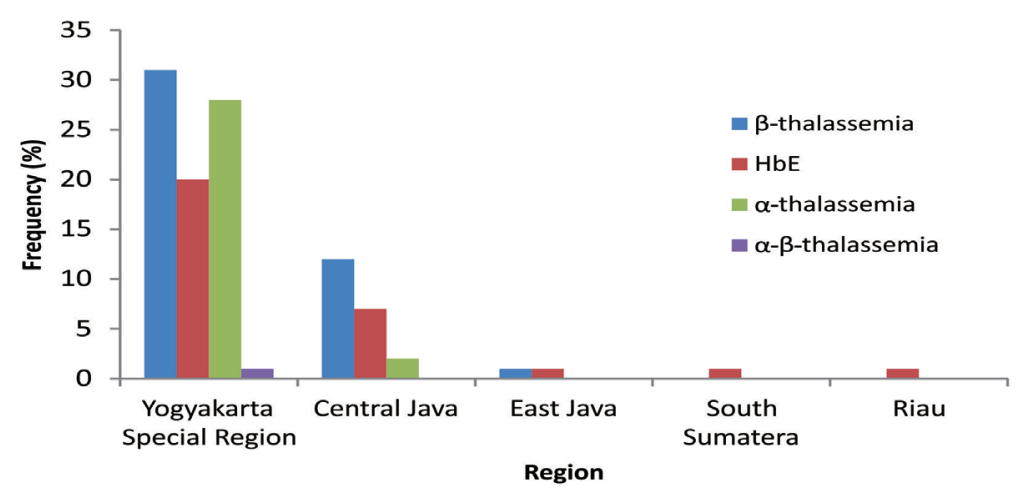

FIGURE 4. Distribution of thalassemia trait in five provinces of Indonesia

\section{DISCUSSION}

The major study of this research was to determine the thalassemia carrier including its prevalence and distribution. Thalassemia carrier can be found when an individual have one or two mutation(s) on a chromosome number 11 ( $\alpha$-thalassemia) and one mutation on a chromosome number 16 ( $\beta$-thalassemia). In accordance to the diagnostic, we used several hematological measurement which were: Hemoglobin ( $\mathrm{Hb})$, Mean Corpuscular Volume (MCV), Mean Corpuscular Hemoglobin (MCH), Mean Corpuscular Hemoglobin Concentration (MCHC), Hemoglobin AA (HbA2) and Hemoglobin F (HbF). ${ }^{11-15}$ The $\alpha$-thalassemia trait can be diagnosed by the low quantity of $\mathrm{MCH}$ and $\mathrm{MCV} .{ }^{15}$ With $\mathrm{HbA}$ reducing and $\mathrm{HbA} 2$ and $\mathrm{HbF}$ increasing, $\beta$-thalassemia carrier can be predicted. ${ }^{11-14,16}$ On this research, we also determined the $\mathrm{HbE}$ disorder carrier which had similar phenotype with $\beta$-thalassemia carrier but had low MCV and $\mathrm{MCH}$ also the peripheral blood film had a normal red cell morphology or minimal morphological abnormalities. ${ }^{7,17}$

Based on FIGURE 1, the prevalence of thalassemia carrier was considered high in Indonesia. The high prevalence can be caused by the gene pool which occurs in some region in Indonesia. ${ }^{18,19}$ In addition, the $\mathrm{HbE}$ disorder carrier also showed the same trend and recorded on every province (FIGURE 4). Furthermore, according to gender depicted in FIGURE 2 , the prevalence for female of thalassemia carrier and $\mathrm{HbE}$ disorder carrier were higher than male. Rather than having any kind of relevance to each other, thalassemia carrier on the other hand is not affected by gender since this carrier is inherited as recessive autosomal disorder. ${ }^{15}$ This phenomenon, could be happened because there was more female than male participant for the whole screening. Thus, the probability to thalassemia carrier in female was higher than male, as well as shown in number of normal volunteers.

On FIGURE 3, thalassemia carrier was always found in each year of the screening. Total number of thalassemia carrier recorded showed no significant difference in each year. It was related with thalassemia carrier prevalence and distribution. Each thalassemia carrier showed different pattern in each years of screening. For $\alpha$-thalassemia, there were two forms which diagnosed silent carrier of $\alpha$-thalassemia and $\alpha$-thalassemia carrier. The carrier form mainly has two deleted copies of the $\alpha$-globin gene, whereas the silent carrier only lacking one $\alpha$ gene. ${ }^{3}$ Silent carrier of thalassemia has no clinical and hematological 
phenotype, ${ }^{9}$ so in this study the carrier which analysed only the $\alpha$-thalassemia carrier. The number of the $\alpha$-thalassemia carrier in 2012 was lower than $\beta$-thalassemia carrier which was 9 volunteers. But in 2013, the $\alpha$-thalassemia carrier was the highest number for the screening, in which 13 volunteers detected with the carrier. In 2014 and 2015, the number of $\alpha$-thalassemia carrier was the lowest than others, in which 6 and 2 volunteers respectively.

The $\beta$-thalassemia, compared to other disorder, was the most common single gene disorder found in the world. It results from variety of molecular defects that reduce $(\beta+-$ thalassemia) or abolish ( $\beta 0$-thalassemia) of the $\beta$-globin chains of hemoglobin. ${ }^{20}$ Inheritance of one $\beta$-thalassemia gene results in the thalassemia carrier (thalassemia minor), inheritance of two defective $\beta$-globin genes, can result in a wide ranged spectrum of clinical conditions depending on the type of b-thalassemia mutation ( $\beta 0$ or $\beta+$-thalassemia) and several other known and uncertain genetic factors. $^{21}$ Number of carrier prevalence for $\beta$-thalassemia carrier in 2012 and 2015 was the highest comparing to other thalassemia carriers. In 2014, number of prevalence for $\beta$-thalassemia carrier was ranked number two and in 2013, its prevalence was the lowest among others. In 2012, we obtained a volunteer with $\alpha-\beta$-thalassemia carrier phenotype. The $\alpha$ - $\beta$-thalassemia carrier is a rare disorder because the carrier has a mutation on each chromosome (chromosome 11 and 16). ${ }^{16}$

Furthermore, $\mathrm{HbE}$ is the most common variant hemoglobinopathies in South East Asian. ${ }^{22}$ It has a nucleotide substitution in $\beta$-globin chain at codon 26 causing glutamic acid substitute into lysine. ${ }^{17}$ This mutation causes a cryptic splice site and makes an abnormal mRNA processing. HbE may be present in homozygous state, heterozygous state, and variety of compound heterozygous states such as hemoglobin E/ $\beta$-thalassemia and sickle cell/hemoglobin E disorder. ${ }^{17}$ On FIGURE 3, HbE disorder carrier was firstly found in 2013 with stable number in the next year of screening, it fluctuated in 9-11 volunteers. The stable number of the prevalence may be explained by the specific mutation site mentioned above, compared to large range mutation of other thalassemia.

As it can be seen, there was a decreasing number of $\alpha$-thalassemia carrier and increasing number of $\beta$-thalassemia from 2013 to 2015 . Since the screening was voluntary basis, it couldn't be termed that the prevalence pattern was as described from the diagram (FIGURE 3). The screening conducted with voluntary basis which was before screening programes, education session and information was provided so attendant were given time to provide consent and able to undergo for the testing. ${ }^{23-25}$ This kind of screening was less suitable to determine prevalence of disorder because the overall screening result is affected by the number of volunteers in each year. However, from the result at least we can know the prevalence and distribution of particular disorder from the screening attendant, which can be used as basic for recommending mandatory screening ${ }^{26}$ or doing further analysis.

On FIGURE 4, we showed that the volunteer came from five province in Indonesia. The most often thalassemia carrier was recorded on province Yogyakarta Special Region, followed by Central Java, and East Java. This occurrence can be caused by the screening location. The screening was conducted on the Yogyakarta Special Region. However, if we focus on the carrier prevalence, the data can be used for determining the thalassemia carrier in Indonesia. Similar researches have been conducted to determine 
the prevalence of thalassemia carrier in Sumatra Island and Medan city. It was reported that more than $7 \%$ of the population of Palembang, Melayu Sumatra was positively $\beta$-thalassemia carriers, approximately $20 \%$ of Sunda Kecil population and 30\% of East Sumba also positively $\mathrm{HbE}$ disorder carrier. ${ }^{18}$ The newest research gained in 2008 informed that the prevalence of $\alpha$-thalassemia and $\beta$-thalassemia in Medan population were $3.35 \%$ and $4.07 \%$ respectively. ${ }^{19}$ This data may complete the basis data of thalassemia carrier distribution. From the paper, we obtained over 241 volunteer, we found 75 volunteers who had thalassemia carrier. Even the distribution is limited by the location where the screening took place, we can conclude that the prevalence for thalassemia carrier is high.

In addition, Indonesia urgently needed more kind of research. There still many province and area in Indonesia which the thalassemia carrier prevalence and distribution remains unknown. Furthermore, through this paper we can know whereabouts the thalassemia and other hemoglobinopathy exist. This used as prevention strategy from thalassemia. Before the disorder seriously become national problem in Indonesia.

\section{CONCLUSION}

From the screening in 2012 until 2015 there are 75 volunteers or almost $45 \%$ are recorded with thalassemia carrier. Most of the disorder volunteers are diagnosed with $\beta$-thalassemia carrier. Total number of thalassemia carrier prevalence shows no significant difference from 2012 to 2015 . The highest number of thalassemia carrier prevalence detected in the screening from 2012 to 2015 is $\beta$-thalassemia, $\alpha$-thalassemia, thalassemia $\mathrm{HbE}$, and $\beta$-thalassemia carrier respectively. Most of thalassemia carrier distribution is recorded on Yogyakarta Special Region, followed by Central Java and East Java.

\section{ACKNOWLEDGEMENTS}

We would like to thank IAPCT Yogyakarta, the ITF, the volunteer on the IAPCT Thalassemia Screening 2012 until 2015 and researchers from Faculty of Biology, Universitas Gadjah Mada, Yogyakarta who supported the research, specifically thank Thalassemia Research Team. We also acknowledge Prodia Clinical Laboratory Yogyakarta for obtaining samples and providing us the hematological data sheets.

\section{REFERENCES}

1. Weatherall DJ, Clegg J. The thalassaemia syndromes. Oxford: Blackwell Scientific. 2001; p:289, 422-439.

2. Weatherall DJ. The Thalassemias. BMJ 1997; 314(7095):1675-8.

3. Langlois S, Ford JC, Chitayat D, Désilets VA, Farrell SA, Geraghty M, et al.Carrier screening for thalassemia and hemoglobinopathies in Canada. J Obstet Gynaecol Can 2008; 30(10):950-71.

4. Thein SL. Genetic modifier of betathalassemia. Hematologica 2005; 90(5):64960.

5. Moosa MM, Ayub MI, Bashar AE, Sarwardi G, Khan W, Khan H, et al. Combination of two rare mutations causes $\beta$-thalassaemia in a Bangladeshi patient. Genet Mol Biol 2011; 34(3):406-9. http://dx.doi.org/10.1590/ S1415-47572011005000026

6. Ikehara K. Advances in the study of genetic disorders. Europe: InTech, 2011; p:101.

7. Fucharoen S, Winichagoon P. Hemoglobinopathies in Southeast Asia: molecular biology and clinical medicine. Hemoglobin 1997; 21(4):299-319. 
8. Rahimi Z, Rezaei M, Nagel RL, Muniz A. Molecular and hematologic analysis of hemoglobin Q-Iran and hemoglobin Setif in Iranian families. Arch Iran Med 2008; 11(4):382-6. http://dx.doi.org/08114/AIM. 008

9. Viprakasit V, Lee-Lee C, Chong QT, Lin $\mathrm{KH}$, Khuhapinant A. Iron chelation therapy in the management of thalassemia: the Asian perspectives. Int J Hematol 2009; 90(4):43545. http://dx.doi.org/10.1007/s12185-0090432-0

10. Steinberg M. Disorders of hemoglobin. Cambridge: Cambridge University Press, 2001; p:431-69.

11. Jandl J. Blood. Boston: Little, Brown: 1987.

12. Hoyer JD, Kroft SH. Color atlas of hemoglobin disorders, a compendium based on proficiency testing. Northfield: College of American Pathologists; 2003.

13. Old JM. Screening and genetic diagnosis of hemoglobinopathies. Scand J Clin Lab Invest 2007; 67(1):71-86. http://dx.doi. org/10.1080/00365510601046466

14. Galanello R, Origa R. Beta-thalassemia. Orphanet J Rare Dis 2010; 5(1):11. http:// dx.doi.org/ 10.1186/1750-1172-5-11

15. Vichinsky EP. Clinical manifestations of alpha-thalassemia. Cold Spring Harb Perspect Med 2013; 3(5):011742. http://dx.doi. org/10.1101/cshperspect.a011742

16. Muncie HL Jr, Campbell J. Alpha and beta thalassemia. Am Fam Physician 2009; 80(4):339-44.

17. Bachir D, Galacteros F. Hemoglobin E disease. Creteil: Orphanet Encyclopedia, 2004; p:2-4.

18. Lanni F, Sofro ASM, Ismadi M, Marzuki S. ISVI-5 (GÆC): the most common $\beta$-thalassemia mutation found in the Island of Sumatera. Indonesian Journal of Biotechnology 2004; 6:571-7.

19. Ganie RA. Distribution of (alpha and beta) thalassemia trait and hemoglobin $\mathrm{E}$ in Medan. Majalah Kedokteran Nusantara 2008; 41(2):117-22.

20. Angastiniotis M, Modell B. Global epidemiology of hemoglobin disorders. Annals NY Acad Sci 1998; 850:251-69.

21. Weatherall DJ, Hoffbrand AV, Catovsky D, Tuddenham EGD. Hemoglobin and inherited disorders of globin chain synthesis in postgraduate hematolog 5th edition. New Jersey: Blackwell Scientific Publishing, 2005; p:85-90.

22. Clarke GM, Higgins TN. Laboratory investigation of hemoglobinopathies and thalassemias: review and update. Clin Chem 2000; 46(8 Pt 2):1284-90.

23. Mitchell JJ, Capua A, Clow C, Criver CR. Twenty-year outcome analysis of genetic screening programs for Tay-Sachs and b-thalassemia disease carriers in high schools. Am J Hum Genet 1996; 59(4):793-8.

24. Zlotogora J, Carmi R, Lev B, Shalev SA. A targeted population carrier screening program for severe and frequent genetic diseases in Israel. Eur J Hum Genet 2009; 17(5):591-7. http://dx.doi.org/10.1038/ejhg.2008.241

25. Cousens NE, Gaff CL, Metcalfe SA, Harper MB. Carrier screening for beta-thalassaemia: a review of international practice. Eur J Hum Genet 2010; 18(10):1077-83. http://dx.doi. org/10.1038/ejhg.2010.90

26. Alhamdan NA, Almazrou YY, Alswaidi FM, Choudhry AJ. Premarital screening for thalassemia and sickle cell disease in Saudi Arabia. Genet Med 2007: 9(6):372-7. http:// dx.doi.org/10.1097GIM.0b013e318065a9e8 